British Journal of Education

Vol.8, Issue 1, pp.55-65, January 2020

Published by ECRTD- UK

Print ISSN: ISSN 2054-6351 (print), Online ISSN: ISSN 2054-636X (online)

\title{
CHANGES IN LIVELIHOOD: DO UNIVERSITIES MAKE ANY DIFFERENCE IN THEIR HOST COMMUNITIES THROUGH CORPORATE SOCIAL RESPONSIBILITIES IN NIGERIA?
}

\author{
Dr. John M. Patrick* and Dr. Mrs.Christina N. Ijah** \\ Department of Adult and Non-Formal Education University of Port Harcourt
}

NIGERIA

\begin{abstract}
In Nigeria, there has been an unprecedented increase in the number of universities. These universities most often are sited in outskirts of urban centres but over the years these communities have become fully urbanized. The question is how has the sitting of the universities contributed to community development and change in the livelihood of its host community through corporate social responsibilities (CSR). The paper argued that community service which is one of the core mandates of university constitutes part of its CSR to its host communities. This paper focuses on two universities host communities in Rivers State Nigeria. Drawing on interviews and focus group discussion, the paper examines the benefits host communities to University of Port Harcourt and Ignatius Ajuru University of Education derived and the negative impact of sitting the of the presence of the university in the communities. The findings suggest a range of positive benefits to the host communities. However, they also highlighted a number of problems that may negatively affect the livelihood of the host community. The benefits include employment of the indigenes, access to quality education, health care and increase economic activities. The negative impacts are increase crime rate and population growth.
\end{abstract}

KEYWORDS: corporate social responsibilities, community service learning, community development, university.

\section{INTRODUCTION}

In Nigeria there has been unprecedented increase in the number of universities. From an initial number of four (4) in the first republic to one hundred and sixty two (162) in 2017; of these number forty (41) are owned by the federal government, forty seven (47) are owned by the state government while seventy four (74) are owned privately by individuals and religious organisations. These universities are established in semi-urban centre, suburbs or urban centres. In some communities, the universities are the major source of economic and social activities. UNESCO cited in Leigha (2010) observed that university education is expected to facilitate desired change and the development of knowledge that will foster and drive socio-economic development. The Federal Government of Nigeria identifies some overarching goals of establishing universities. These are intensifying and diversifying its programmes for the development of high level manpower within the context of the needs of the nation; making professional course content to reflect our national requirements; making all students as part of the general programme of all round improvement in university education to offer general study courses as history of ideas, philosophy of knowledge and nationalism. In furtherance of these goals, the universities are expected to: 
British Journal of Education

Vol.8, Issue 1, pp.55-65, January 2020

Published by ECRTD- UK

Print ISSN: ISSN 2054-6351 (print), Online ISSN: ISSN 2054-636X (online)

1. Contribute to national development through high level relevant manpower training;

2. Develop and inculcate proper values for the survival of the society

3. Develop the intellectual capability of individuals to understand and appreciate their local and external environments and

4. Acquire both physical and intellectual skills which will enable individuals to be self-reliant and useful members of the society among others.

In all of these avowed objectives for which universities were established, the local communities in which they operate is not considered. The universities do not operate in a vacuum; they are sited in communities that are the host. The universities seat in vast arable hectares of land and become a community of its own within a community. In most cases these lands are acquired by the owners of the university (federal government, state government, religious bodies or private investors) with little compensation or nothing to the community. The communities donate their land willingly or take little compensation for their arable land with the expectation that the sitting of the university campus in their community will bring about tremendous social and economic benefit to their people. There are indeed many potential benefits that a host community to a university campus could derive. The universities apart from teaching and research have the mandate to carry out community service which the host community may be the immediate beneficiaries. Community service according to Wright (2009) is an experiential learning model in which university students are sent from their institutions to volunteer their time, energy, skills and expertise and enthusiasm in diverse range of community based initiatives. Community service is part of the corporate social responsibilities (CSR) of universities to their host community. Unlike the multinational companies, the reason behind such CSR is not to obtain social license to operate but to promote research and teaching and bring to bear their research findings to their immediate community.

The idea of CSR that is business bearing responsibility to society and a broader set of stakeholders beyond its owners have become increasingly common to multinational companies. Companies have used the CSR to address pressing societal challenges and contribute to the development of their host communities. Companies operating in weak governance context often embark on short term or long term projects as their CSR to fill the development gap in communities where they operate (Van Alstine and Afionis, 2013). Most research on CSR focuses on multinational companies. Wrange, Tong, Takeuchi and George (2016) point out that current research on CSR emphasizes business as positive and responsible contributors to society and as tools with which to shape and facilitate social change. But in respect of university's community service to its host community as part of CSR there is limited research. The few that exist does not focus on the livelihood changes in the host communities. Notable examples of such research are that of the works of Reed and Marienau (2008) and Sandman, Kiely and Grenier (2009). These studies provide an adult education perspective of community service learning with focus on community development. It is against this backdrop that this study seeks to investigate the livelihood changes in host communities to universities in Nigeria under the broad framework of CSR of universities to their host communities and with emphasis on community service to the host communities. To do this, the study is carried out in Rivers State. Two universities' host communities provide the 
British Journal of Education

Vol.8, Issue 1, pp.55-65, January 2020

Published by ECRTD- UK

Print ISSN: ISSN 2054-6351 (print), Online ISSN: ISSN 2054-636X (online)

arena for this study. The universities are University of Port Harcourt and the Ignatius Ajuru University of Education Port Harcourt.

\section{Global Perspectives in Community Services and University CSR Initiatives}

Community service learning has become a popular pedagogy in United State of America and other parts of the world. It is similar to the ethics and land grant research university system in U.S; and the extension education programme in general. Extension education programmes are community based programmes initiated to meet specific needs of the community outside the formal university programme. It provides local people and communities with practical research based knowledge to improve agriculture, literacy, home economics, environmental conservation and community development. It is a way for universities to be involved in community issues. It usually takes the form of non-formal education programmes, field visits by extension officers who are adult educators, agricultural extension officers, health personnel, historians, environmental conservationist. According to Walter (nd) community service learning (CSL) is different from extension programme as the CSL learning provides practical knowledge through the extension system not of experts' researchers knowledge and faculty, but relatively novice university students. This implies that CSL is not limited to specific area of study. All university programmes have relevance to community needs and applicability to solve community problem. The CSL is an experiential learning framework that provides the students the opportunity to put their theoretical learning to the test of practical application and for them to volunteer their labour and to bring to bear the knowledge so far gained in meeting the needs of the community. It is a learning process because the students in most cases gain more practical knowledge from the community. It is designed to meet the learning objectives of the university curriculum. In some universities it is one of the courses that the students are expected to take to meet the course requirement for graduation. However, it must be noted that as the students embark on such services that they will be able to solve a given community development need of the community and improve the socio-economic wellbeing of the community.

CSL is within the purview of adult education particularly in the areas of community education and community development. CSL and adult education share a number defining characteristics. Both seek to accentuate social change through education. Both also generate new knowledge for the benefit of the local community; campaign and public enlightenment on specific issues of concern in the community; learning is informal, incidental and experiential. The Delor's four pillars of learning come to the fore in the CSL as both the students who volunteer their service for the community and the community members are engaged in the various aspects of Delor's pillars of learning. These are: learning to learn, learning to be, learning to live together. This learning is also transformative to both the students and the community people.

Butin (2003) identifies four conceptualizations of CSL. These are technical, cultural, political perspectives. The technical perspective entails community based structured and process technology programme involving the students in the community. Through this type of CSL the students apply new technology to meet pressing community needs in areas of agriculture, medical care, housing and sanitation. The cultural perspective entails students' historic, civic and democratic engagements in the community. They participate in cultural festivals, develop greater 
British Journal of Education

Vol.8, Issue 1, pp.55-65, January 2020

Published by ECRTD- UK

Print ISSN: ISSN 2054-6351 (print), Online ISSN: ISSN 2054-636X (online)

tolerance, understand the history and culture of the people and its diversity, become better aware of social issues and engage in civic and democratic processes. The political perspective is like the cultural perspective but a lot different in respect of its emphasis on transformative experience in the CSL. In the political perspective the emphasis is on how students will better understand power relations and social conflict and then act with the local communities to challenge oppressive relations.

There are also two contending perspective of community service learning as practiced over time. The first is the international CSL and transformative learning from the cultural perspective; and the second is the CSL for social justice from the political perspective. Crabtree (2008) writing on the international trend of the cultural perspective, argues that beyond being a pivotal cross-cultural experience for students, the international perspective is also a form of participatory development which could be included in community based research and transformative learning for participants in community based initiative. On the other hand, the second perspective which focuses on social justice is aimed at bringing about social change in the community.

Several reports on the practice of the CSL by universities and the benefit of such services to students and communities abound. Wright (2009) reported a raise in awareness and the commitment to global human right by students under the CSL in the International Amnesty programme in communities in Canada. Similarly, Kiely (2004) shows how students' involvement in the community health issues lead to transformative learning in Nicaragua. Similarly, Mitchell (2007) reported that citizen-scholar programme, a CSL programme in the University of Massachusetts results in critical social justice orientation and develops students' abilities to promote social change in the community. In Canada, at the Frontier Colleges' labourers-Teachers Programme, University students are sent out to live, labour and teach literacy among working immigrants in mining, rail, agriculture and farming camps (Walter, 2003).

In the University of British Columbia under the CSL, students are placed in the inner city schools, homeless shelters, drop-in-centre, hospices and other community settings as volunteers doing several services related to their field of study and other social works on a voluntary basis. The British Columbia's CSL is a combination of three key elements: students doing volunteer work in the community, some kind of academic content, and structured reflection. This system of CSL enables the students to think critically about the connection between what they see and experience in the community and what they study in the class room. Here the goals of CSL as pointed out by Feyer (2009) are: first, to enhance students' learning about themselves and their roles as global citizens; about critical community issues; and about academic fields of knowledge. Secondly, to apply the resources of the university (people, knowledge, and methods of inquiry) to critical community issues (social, ecological, and economic). Thirdly, to build and strengthen the capacity of the university, community organizations, and foster university-community partnership. It must be noted that CSL is different from student industrial attachment which is specifically designed for students to acquire practical experience from the industries.

Apart from the CSL through which universities can contribute to its host community development under its CSR, universities have been seen providing services to its host communities. Universities 
are seen providing electricity and water to its host communities. For instance it was reported that the University of Pennsylvania invested in local housing restoration, area retail development projects, and lighting installation for 1200 West Philadelphia properties. This university also created working relationship with community based organisations to acquire and use information technology for neighbourhood development purposes (Martin, Smith and Philips, 2009). Furthermore, universities under the CSR have been involved in building community capacity. For example in Massachusetts Institute of Technology (MIT), in an effort to rebuild its host community, the institution developed a Neighborhood Technology Centre Programme. The programme is called 'Creating Community Connection'. The essence of the programme was to provide access to computer training to improve community safety, recreation, continuing education, and employment opportunities. In this programme, once a resident of the host community was trained on computer at the centre and is adjudged to be computer literate, a computer with internet access will be installed in his/her home. According to Roper and Pinkett, (2002), the institution used this project to improve the quality of life of the host community.

Universities have the potentials to facilitate societal changes and respond to challenges because of its three fold functions. These are: research, teaching and community service. With these functions Faculty, students and administrators are increasingly contributing to pedagogical and intellectual value; connecting their work in explicit ways with communities outside the campus. At the same time, depressed and troubled communities are turning to universities to provide resources, knowledge and assistance in addressing perplexing social problems as government capacity to resolve some of these community problems continue to diminish as a result of declining revenue base occasion by economic recession and financial crisis. This phenomenon has led to Community-University partnership, and a platform for collaboration. This is quite different from community based action research which dates back to 1930's as result of the seminal paper of Kurt Lawin and Paul Freire as cited by Faridi, Grunbaum, Gray, Franks, and Simoes (2007). Thus it is in these various perspectives that CSR of universities can be situated and the basis upon which the sitting of university campus in a community can bring about a change in the livelihood of the community members and foster sustainable community development.

\section{DATA AND METHODOLOGY}

A qualitative survey was conducted in two communities in Rivers State where two universities are sited. The communities are Choba and Rumuolumeni all in Obio/Akpo Local Government Area in Rivers State, Nigeria. The survey was conducted within March to June 2019 in the two communities. These communities are host to University of Port Harcourt and Ignatius Ajuru University of Education respectively. Our choice of these communities and the universities is that these communities were suburbs of Port Harcourt small outskirts in 1970's when these institutions were established, but now have become increasingly urbanized communities. Thus, these communities provide an appropriate arena to examine whether the sitting of university in a community have changed the livelihood of the community and to assess the impact of universities' CSR in the host communities. 
The key instruments for data collection were the focus group discussion (FGD), key informant interview, and observation. We conducted two FGDs comprising of seven persons per group in each of the communities. The FGD was made up of men and women who were 50 years old and above while the other was made up of younger people who were between 25 and 40 years old. The number of women that participated in each of the FGD ranges from 2 to 3. The FGD was complemented by unstructured key informant interviews with the leadership of the community governance institutions in the community. Specifically, we interviewed the members of the Community Development Community (CDC) which include the Chairman, Secretary and five others, the Youth Chairman/President and the Women Leader as while as Market Leaders. On the whole, 24 persons from the two communities participated in the FGD, 60 persons were interviewed, 30 from each community amounting to a total of 84 participants. The justification for the selection of people in the FGD and the interview is that they are all stakeholders in the community. A snowballing sampling strategy was employed to ensure the views of hard-to-reach groups, such as women were obtained. The FGD and interviews were tape recorded and transcribed. The FGD and the interview of the key informant interview focuses on the livelihood changes that the communities have experienced over the years since the establishment of the universities in the respective communities, the contribution of the university to community development in respect of educational development, employment opportunities, infrastructural development and local economic development, the nature of community service and how relevant is the community service to the needs of the community, and what are the expectations of the community from the university.

\section{FINDINGS AND DISCUSSION}

\section{Community Benefits from the Universities}

Regarding the benefits of the sitting of the university in their community, the study reveals that four discernable areas where identified as areas where the communities expected to gain from the universities. These were in areas of giving the community certain quota in admission of students into the various programmes of the university, employment quota, provisions of social services and infrastructure in the community. Sentiments among participants in the FGDs and key informant interview on the benefits of the hosting of the universities in their community were somewhat mixed. The participants in Choba community, the host to University of Port Harcourt pointed out that they expected the university to give their children and wards scholarship and special consideration in admission into various programmes of study rather than being subjected to the same competitive admission test with people from other communities. The participants pointed out that although there has been some form of consideration or admission quota given to the community. the respondents during the survey complained that the problem here is that only the Nyewe-ali (the paramount ruler) and a few of his council of chief appropriate the opportunity and that sometimes the community quota is filled by non-natives because prospective students from the community do not meet the cut of point set by the university for the host community. The similar views were expressed by the people of Rumuolumeni a community that is the host to Ignatius Ajuru University of Education. 
In respect of employment opportunity for the indigenes of the host community, the respondents pointed out that the universities employ the community people in various categories but more in junior category. They pointed out that their women are employed as casual workers as cleaners and sweepers in the university and the unskilled men as labourers and security. They also pointed that the pattern is the same in admission. The employment opportunity according to the respondents in Choba community th were appropriated by the friends and members of the immediate family of the Nyewe-ali and few of his council of chiefs. The respondents in Choba community pointed out that since the establishment of the University of Port Harcourt in 1975, the community has not been able to produce any principal officer like the Vice Chancellor or Registrar of the university, that for over 43 years of the establishment of the university in the community, the community can only boost of one professor in the university. Here the pattern is slightly different as in Rumuolumeni, as the community people are well considered for employment in both senior and junior categories and not as casuals under a contractor.

In respect of provision of social service and infrastructure, the respondents pointed out that the universities have not sited any social infrastructure in their host community, but that they benefit from several social services and infrastructures of the university. They pointed out that they send their children to the staff primary and secondary schools; fetch quality drinking water from the university campus and access the university teaching hospital though not in a subsidized rate. The respondents in Choba pointed out that the University of Port Harcourt Teaching Hospital is the only nearest tertiary hospital to the community. One of the participants in the FGD noted that:

The Rivers State government no dey fair to our community in respect of provision of infrastructure. The government dey collect a lot of revenue from the big big companies in our community since the days of Welbros and Hallibutten and now Indomie. Our community gave out the technical school built by the government in our community in 1975 for the takeoff of the University of Port Harcourt. Since then, the government of Rivers State has not sited any social infrastructure in the community. We do not have hospital, no government secondary school, no public water. But all of these can be found in the university campus and in our neighbouring communities. We prefer to use the university teaching hospital and send our children to the university secondary and primary school because the quality dey high for people way fit to pay like every other person.

This sentiment expressed by this respondent was the general feeling of the community members who engaged in the FGDs and in the key informant interview. On the other hand, the respondents were satisfied with the youth empowerment programme recently initiated by the university Community Service Unit and the Entrepreneurial Centre. Under this programme 33 youths were trained on various skills such as structural welding, paint making and fashion design. One of the participants recounted the words of the Vice Chancellor that by this training programme it is clear that the university is living up to its core mandate of teaching, research and community service. When one of the beneficiaries of the skill acquisition was interviewed he had this to say:

The last time the youths from this community was given this kind of training was in 2014 when the university organized computer training programme for some youths. We expected the university to organize more of this type of training to empower the youths to become self-reliant 
and employer of labour. With the skill I have acquired, I can open my own welding shop, employ and training one or two persons also. If this programme is continued in the next five years and the youths were able to put the skills acquired into practice, so many of our youths on the streets that have resort to crime will be meaningfully engaged and be out of crime.

Turning to environmental sanitation, the respondents acknowledged that the university community service embarked upon by the students has been very helpful in keeping the community clean. They said they use to see the university students with their working tools (cutlass, hoe and wheelbarrow) in the morning in their numbers regularly in the Choba market, the court premises and town square clearing refuse, cleaning the drainage, and cutting grass along major road. These activities, the participants all agreed has been an age long practice by the university. But some of the participants complained that the chiefs often divert the students to places other than areas of the need and their personal premises.

Similarly, the participants pointed out that students are also seen in the community doing some form of rally or public enlightenment such as public enlightenment and education on HIV/AIDS including free screening and testing, Sickle Cell awareness campaign and other health related issues. These various health campaigns were some of the community service outreach programmes carried out by the students of the College of Medicine. In the sickle cell awareness campaign, it was reported that 200 persons benefited from the free vital signs checks and blood test. In Rumuolumeni none of these are applicable. The community does not access any of these services from the university nether does the university sited in the area carries out community service learning of any sort in the community. However, it was reported that the present Vice Chancellor who was appointed from the University of Port Harcourt, just introduced community service learning, but the kind of community service done by the students is different from that of University of Port Harcourt. In the Ignatius Ajuru University the student community service is carried out only on the university campus and not in the host community. The newly produced SCL is called The Student Tangible Project. The hallmark of the project is painting of the various class room blocks and hostels by the students.

\section{Economic Impact and Change in Livelihood in the Host Community}

Some participants in the FGDs and Key Informant Interview pointed out positive impact and the multiplier effects of sitting university in their community. The participants pointed out the spring up of various retail outlets, fast food shops, banks, small scale industries, transport business, student hotels, housing estates, hotels, bars and night clubs and other business outfits in the community. They also pointed out that there has been tremendous growth of the community with increasing university students and staff population as while as business people resident in the community. According to them the non-indigenous population has outnumbered the indigenous population. This has made estate business very lucrative and increase size of the local market. The participants pointed out that the people of the host communities are traditional fisher folks and farmers, but with the establishment of the university in their community they now found a new source of livelihood. They now shift from been peasant farming and antennary fishing to white and blue color workers as while as petty traders. This is applicable to both communities. 
A number of participants in the FGDs and the Key Informant Interview reported mixed impacts of the sitting of university in their community. They pointed out that presently the community lacks arable land for farming as the universities occupy vast hectares of land, staff, estate developers and land speculators acquire the rest of the farm lands for estate development which has become a very lucrative business in the community. They also pointed out that accommodation in the community has become very expensive; most of the indigenes without a decent source of livelihood and without personal houses cannot afford decent accommodation. Crime rate has also increase with most of the student cultists and the university drop outs now perpetuating their cultic and criminal activities in the community. According to some of the participants, the community now houses cultist and criminal bandits. Life in the community have become insecure, night life is not guaranteed as these boys go about harassing people deriving people of their valuable properties like phones, laptops and other electronic gadgets. The respondents stated that these boys who indulge in such criminal arts cannot perpetuate such criminality on campus because of the tight security architecture.

The above findings highlight a rather uncoordinated approach to CSR by universities to its host community through community service which is one of the core mandates of a university. First, the universities do not have any Memorandum of Understanding (MoU) with their host communities to carry out any obligation in the communities. But it is also incumbent on the part of the universities to extend its community service to its host communities to create a cordial relationship and peaceful atmosphere for academic activities. This perhaps is what has informed such policies like reserving certain admission quota and employment opportunities to the host communities. The inability of the communities to effectively utilize such opportunities as the findings indicated hinges on: one, the fact that universities being centres of excellence would not compromise its standard and allow mediocrity and as such would not lower its standard for its host communities. This perhaps is why the Choba community since the establishment of the University of Port Harcourt over 40 years ago can only boost of only one professor and no principal staff as while as the inability of the communities to fill its admission quota. Secondly, the fact that a few individuals in the community appropriate the employment opportunity and the admission quota indicate that the chances are not thrown open to the community people. Most of the people in the community are not aware of such opportunities given by the universities. This may create mistrust between the community leaders and the ordinary people in the community as while as between the community and the universities. However, the granting of admission quota and giving the community opportunity for employment are affirmative action for human capital development in the community that could change the livelihood of the host community.

The study also reveals that the universities have done nothing in respect of infrastructural development in the host communities. This is perhaps based on the fact that the universities operate with limited financial resource and has its own pressing infrastructural demands that the government has not been able to meet. But the universities in the face of this financial constrains can partner with the community, non-governmental organisations and the government in designing and execution of community-based projects using its technical knowhow. It is not until the universities have financial sufficiency that it should venture into community-based projects in its host communities. It can adopt the community development model of the National Youth Service 
Scheme where youth corp members source for fund to embark on community development projects. The universities adopting this strategy will foster a sense of volunteerism in its students. This pattern of community of service will be in line with the global perspective of community service learning as enunciated by Butin (2003) where students take up technical projects or programmes to meet pressing community needs in areas of agriculture, medical care, housing and sanitation.

The present model of CSL as practiced in the University of Port Harcourt is ad hoc, one directional and top down in nature and is not in tandem with best practice in CSL and community development. First, the programme is not based on careful analysis of the community needs using need assessment or the current asset based community development (ABCD) practice. Secondly, its process is not inclusive involving the community members and its outcome does not add to the stock of community asset and may not change the livelihood of people in the community. Interestingly, the Community Service practiced in University of Port Harcourt is drainage cleaning. This cannot lead to sustainable community development in the host community. But the community outreach programme as organized by the university by its design and implementation can be likened to community intervention as enunciated by Rosato (2015). Here the university embarks on short term clinical methods or programmes to address physiological risk factors. The community forms the settings and passive recipients of the solution provided by the university. The findings highlighted show a significant change in the livelihood of the community people as a result of the sitting of university campus in their communities. Historically, livelihoods in the communities are embedded in the nature of their occupation and their culture. The people are traditional farmers and fisher folks. Contemporary livelihoods in the community are diverse beyond fishing and farming; the people cannot do much of the farming and fishing. They cannot do much of the farming activities because of the usurpation of their land by land speculators who have acquired the lands to meet the increasing needs of students and staff accommodation. The study reveals that the people of the community now participate in the new economic activities which has spring up such as rent taking from estate business, petty trading, transport business (which include toll taking), white and blue color jobs in the universities and other industries and enterprise within the community. These various economic activities have changed the traditional economic activities of the communities to a more modern and capitalist economy driven by a rentier system. That is where the people depend on rent as their source of livelihood.

\section{CONCLUSION}

Can sitting university contribute positively to community development and livelihood change in its host community in Nigeria? The analysis in the preceding section has shown that despite the limiting financial resources of the universities, that university stimulates economic growth and change in the livelihood of people in its host communities. The case presented here shows that Choba and Rumuolumeni communities that are host communities to university of Port Harcourt and Ignatius Aguru University of Education respectively, experience tremendous changes in their development process from being a small enclave close to city centre to now an integral part of the city and being fully urbanized. Also, the study shows that the communities from being a traditional fishing and farming communities is now a modern capitalist society driven by rentier economy, 
British Journal of Education

Vol.8, Issue 1, pp.55-65, January 2020

Published by ECRTD- UK

Print ISSN: ISSN 2054-6351 (print), Online ISSN: ISSN 2054-636X (online)

petty trading and white color job. The multiplier effects of the sitting university are enormous in the host community. But the externality of the sitting of the university includes among others the increase in crime rate and the haulage of the people from the traditional occupation and values.

\section{References}

Butin, D. (2003). Of what use is? Multiple conceptualization of service learning within education. Teachers College Record 105 (9), 1674-1692.

Crabtree, R. D. (2008). Theoretical foundations for international service-learning. Michigan Journal of community service learning, Fall 18-36.

Faridi, Z., Grunbaum, J. A., Gray, B. S., Franks, A. \&Simoes, E. (2007). Community based participatory research: necessary next steps. Public Health research Practice and Policy $4(3), 1-5$

Fryer, M. (2009). University of British Columbia-Commuinity learning initiative third annual report to the J.W. McConnell Family Foundation. <http://www.learningexchange.ubc.ca/ubc-cli.html>

Kiely, R. (2004). A chameleon with a complex: searching for transformation in international service-learning. Michigan Journal of Community Service Learning, Spring, 5-20

Leigha, M. B. (2010). Carrying capacity of universities and skill acquisition for optimal attainment of vision 20-2020 in Nigeria. Proceeding of the $25^{\text {th }}$ Annual Congress of Nigerian Academy of Education. Abuja: NERDC, 108-120.

Martin, L. L., Smith, H., \&Philips, W. (2005). Bridging 'town and gown' through innovative university-community-partnership. The Innovation Journal, 10(2), 1-13

Mitchell, T. D. (2007). Critical service-learning as social justice education: a case study of the citizen scholar programme. Equity and Excellence in Education, 40(2), 101-112

Reed, S. Marienau, C. (eds). (2008). Linking adults with community promoting civic engagement through community based learning. New Directions for Adult and Continuing Education. San Francisco: Jossey Bass.

Rosato, M. (2015). A framework and methology for differentiating community intervention forms in global health. Community Development Journal, 50(2), 244-263.

Sandmann, L. R., Kiely, R. \&Grenier, R. (2009). Programm planning: The neglected dimension of service learning. Michigan Journal of Community Service Learning, Spring, 17-33.

Van Alstine, J. \&Afionis, S. (2013). Community-company capacity: the challenge of resource-led development in Zambia's New Copperbelt. Community Development Journal, 48, 3, 360376.

Wrange, H., Tong, L., Takeuchi\& George, G. (2016). Corporate social responsibility: An overview and new of research directions. Academy of Management Journal, 59(2), 534-544.

Walter, P. (2003). Adult literacy education on the Canadian frontier. Adult Basic Education, 13(1), 3-18.

Wright, D. (2009). A service learning and social action case study: Growing a culture of respect for human right. Proceeding of the Western Regional conference on Adult Education (WRRCEA) oct. 23-25 Bellingham WA. 